\title{
Concepts and Realities of Social Enterprise: A European Perspective
}

\author{
Jacques DEFOURNY (University of Liège, Belgium) \\ Paper presented at the Second Research Colloquium on Social Entrepreneurship, \\ Duke University, NC, June, 23-26, 2009
}

\section{Introduction}

Although rarely used until the mid-1990s, the concepts of "social enterprise", "social entrepreneurship" and "social entrepreneur" are now increasingly discussed in various parts of the world. The bulk of the literature is still being produced in Western Europe and the United States but those three "SE flags" are attracting much interest in other regions, such Central and Eastern Europe, South-Eastern Asia (especially South Korea, Japan and Taiwan) and Latin America.

In Europe, the concept of social enterprise made its first appearance in 1990, at the very heart of the third sector, following an impetus which was first an Italian one and was closely linked with the co-operative movement: a journal named Impresa sociale (Social enterprise) started to study new entrepreneurial initiatives which arose primarily in response to social needs that had been inadequately met, or not met at all, by public services. ${ }^{1}$. In 1991, the Italian parliament adopted a law creating a specific legal form for "social co-operatives" and the latter went on to experience an extraordinary growth. Around the same period, European researchers noticed the existence of similar initiatives, though of a lesser magnitude, in various other EU countries and in 1996, they decided to form a network to study "the emergence of social enterprise in Europe". This network, which was named EMES and covered all of the fifteen countries that then made up the European Union, gradually developed a common approach of social enterprise.

In the United States, the concepts of social enterprise also met with a very positive response in the early 1990s. In 1993, for instance, the Harvard Business School launched the "Social Enterprise Initiative", one of the milestones of the period. Since then, other major universities (Columbia, Berkeley, Duke, Yale, New York etc.) and various foundations have set up training and support programmes for social enterprises as well as social entrepreneurs. As to the latter, Ashoka, an organization which has identified and supported such a type of individuals since the beginning of the 1980s has played a pioneering role in this line ${ }^{2}$.

In a first period - and still today outside specialists' circles- , the three SE concepts have been used more or less along the same lines: although simplifying a little, one could say that social entrepreneurship was seen as the process through which social entrepreneurs created social enterprises. Afterwards, various definitions of and

\footnotetext{
${ }^{1}$ Borzaga and Santuari (2001).

2 First referred to as "public entrepreneurs" by B. Drayton, who founded Ashoka, these individuals have been termed "social entrepreneurs" from the mid-1990s onward, and increasingly presented as heroes of modern times (see for example Bornstein 2004). Dees (1998) put forward the most often referred definition of a social entrepreneur.
} 
approaches to each of these concepts have been proposed. However, what is striking is the fact that the debates on both sides of the Atlantic took place in parallel trajectories, with very few connections among them throughout the 1990s and even the first half of the following decade ${ }^{3}$. Moreover, along these years in Europe, the concept of social enterprise was the only one which really became increasingly used, although to various extents across countries. In such a context, it surely makes sense to carefully analyse how the social enterprise idea spread throughout Europe and gave birth to a quite distinct literature as well as to show how the European conceptual landscape evolved in the last years, including through a much deeper dialogue with US academic and field actors.

Before going further, it should be noted that the SE concepts can in practice be used to point out two quite different phenomena: on the one hand, they designate new organisations, created ex nihilo that may often be viewed as a sub-group of the third sector; on the other hand, they can also designate a process, a new entrepreneurial spirit influencing and re-shaping older third sector initiatives.

In this perspective, we therefore begin with a brief discussion of the main approaches that, for more than a quarter century, have been developed to apprehend the realities of the third sector (section 1). Subsequently, we will assess the extent to which one can speak of the rise of a new social entrepreneurship within this sector in Europe (section 2) and how this social entrepreneurship can be apprehended from a conceptual point of view, both through the definition proposed in 2002 by the British government when it launched an active policy for the development of social enterprises and through the approach built by the EMES European Research Network since the mid-1990s (section 3). Because of their truly European scope, a particular attention will be paid to EMES empirical works in the first $15 \mathrm{EU}$ member states and in the new member countries from Eastern and Central Europe (section 4). The theoretical potential of this approach will be highlighted (section 5). It will also be analysed in the light of the most recent evolutions on the North-American scene (section 6).

\section{The (re)discovery of the third sector}

The idea of a distinct third sector, made up of enterprises and organisations which are not part of the traditional private sector nor of the public sector, began to emerge in the mid-1970s. Such organisations were already very active in many areas of activity and were indeed already the subject of scientific works and specific public policies. But the idea of bringing these bodies together and the theoretical basis on which this might be done were not really put forward until 30 years ago.

In the United States the work of the Filer Commission and, in 1976, the launch of Yale University's "Program on Non-profit Organisations", involving 150 researchers, marked a decisive step in the conceptualization of non-profit organisations (NPOs) and the non-profit sector. Since then, a vast scientific literature on NPOs has been developed, with contributions from disciplines as diverse as economics, sociology, political science, management, history, law etc. ${ }^{4}$

\footnotetext{
${ }^{3}$ From a scientific point of view, the first bridges were built by Nicholls (2006), Mair, Robinson and Hockerts (2006) as well as Steyaert and Hjorth (2006).

4 See journals like Nonprofit and Voluntary Sector Quarterly published by the Association for Research on Nonprofit and Voluntary Action and Voluntas published by the International Society for Third Sector Research.
} 
In Europe, the broad diversity of socio-political, cultural and economic national circumstances has not allowed such a wide-ranging and rapid development of analytical works emphasizing the existence of a third sector. However, the economic entities that gradually came to be perceived through a third sector approach were already important in most countries. They were also rooted in solid and long-standing traditions: mutual organisations and co-operatives had existed more or less everywhere for more than a century, and association-based economic initiatives had also been multiplying for a considerable time.

In fact, without denying that the general public's view is still strongly characterised by the historical context of each country, it may be said that two conceptual approaches aiming to embrace the whole third sector gradually spread internationally, accompanied by statistical work aiming to quantify its economic importance. One is the already-mentioned "non-profit sector" approach; the other, mainly French in origin, forged the concept of the "social economy" to bring together co-operatives, mutual societies and associations (and, with increasing frequency, foundations). 5 Although the first approach has the great advantage of having been conveyed, from the outset, by the English language, the second approach has found an ever-greater resonance throughout Europe and in other parts of the world ${ }^{6}$. It has also been taken up, although not always with the same meaning, by the European Union's institutions. $^{7}$

Other conceptualizations of the third sector have also been developed and have met with a positive response at the international level. This is in particular the case of approaches based on a "tri-polar" representation of the economy, where the three "poles" either represent either categories of agents (private enterprises, the state, and households), or correspond to logics or modes of regulation of exchanges (the market, public redistribution and reciprocity), which in turn refer to the types of resources involved (market, non-market and non-monetary resources). In such a perspective, the third sector is viewed as an intermediate space in which the different poles combine ${ }^{8}$. The analytical grid of the solidarity-based economy belongs to such a perspective. Although sometimes regarded as competing with the first two concepts, these last approaches rather provide analytical grids which enrich the understanding of the nonprofit sector and the social economy.

The importance of this third sector is nowadays such that one can affirm that it is broadly associated with the major economic roles of public authorities: the third sector is involved in the allocation of resources, through the production of many

\footnotetext{
5 See for instance the French Revue des Etudes Coopératives, Mutualistes et Associatives (RECMA). The concept of social economy had already been used across various European countries in the $19^{\text {th }}$ century to refer to the emerging cooperative societies, the friendly societies, the developing building society movement and other philanthropic and charitable organisations. See for instance the Scottish political essayist and historian Samuel Smiles in his work Thrift first published in 1875 or Gueslin (1987) for an overview of all schools of thought which contributed to the development of the social economy in France during the $19^{\text {th }}$ century.

6 World-wide social economy research conferences are being organized every two years under the auspices of CIRIEC which also publishes the Annals of Public and Cooperative Economics, a 100 years old scientific journal rather close to social economy topics.

7 There has existed for a long time now an inter-group "social economy" within the European Economic and Social Committee and the European Parliament. Moreover, the action programmes as well as the decisions made by the European Council of Ministers increasingly refer to the social economy.

8 See, among others, Evers and Laville (2004).
} 
quasi-public goods and services (in the fields of health, culture, education, social action, proximity services, sport, leisure, the environment, advocacy etc.); it has a role of redistribution of resources, via the voluntary contributions (in cash, in kind or through volunteering) which many associations can mobilize and through the provision of a wide range of free or virtually free services to deprived people; and it is also involved in the regulation of economic life when, for example, associations or social co-operatives are the privileged partners of public authorities in the task of helping low-qualified unemployed people, who are at risk of permanent exclusion from the labour market, and reintegrating them back into work.

The persistence of high structural unemployment in many countries, especially across Europe, as well as the difficulties of traditional public policies in coping with new economic and social challenges, have naturally raised the question of how far the third sector can help to meet these challenges and perhaps take over from public authorities in some areas.

Of course there is no simple answer to this question, and the debate is today wide open. Some regard associations and other third sector entities as made-to-measure partners for new transfers of responsibility and parallel reductions in public costs. The qualities usually attributed to private enterprise (flexibility, rapidity, creativity, a willingness to take on responsibility etc.) are also expected to lead to improvements in the services provided ${ }^{9}$. Others, on the contrary, fear that the third sector might become an instrument for privatisation policies, leading to social deregulation and the gradual unravelling of acquired social rights. Others still stress the fact that our societies are moving towards a redefinition of relationships between the individual, the intermediate structures of civil society and the state.

In any case, most would share the view that Western European countries are moving from a "welfare state" to a new "welfare mix", where new bases are to be found for the sharing of responsibility among public authorities, private for-profit providers and third sector organisations.

\section{A new social entrepreneurship}

Why does it make sense to talk about a new social entrepreneurship and not simply of an evolution of non-profit or social economy organisations? This question refers directly to the theories about entrepreneurship, which we do not intend to review in the present chapter. We will simply refer to the classic work of Schumpeter, for whom economic development is a "process of carrying out new combinations" in the production process ${ }^{10}$ and entrepreneurs are precisely the persons whose role it is to implement these new combinations. According to this author, entrepreneurs are not necessarily the owners of a company, but they are responsible for introducing changes in at least one of the following ways: i) the introduction of a new product or a new quality of product; ii) the introduction of a new production method; iii) the opening of a new market; iv) the acquisition of a new source of raw materials; or v) the reorganisation of a sector of activity.

Following the work carried out by D. Young (1983) and Ch. Badelt (1997), this typology can be adapted to the third sector; for each of the levels mentioned by

\footnotetext{
${ }^{9}$ Such an argument had become classical in the Blairist construction of the "Third Way".

${ }^{10}$ Schumpeter (1934:66).
} 
Schumpeter, it can be asked to what extent a new entrepreneurship can be identified within the European third sector. ${ }^{11}$

\section{New products or a new quality of products}

Numerous analyses of the third sector have already demonstrated that the latter has often developed in response to needs to which the traditional private sector or the state were unable to provide a satisfactory answer. ${ }^{12}$ There are countless examples of organisations that have invented new types of services to take up the challenges of their age. To this extent, many of these organisations can be said, nowadays as in the past, to be born or have been born from an entrepreneurial dynamic. But have the last two decades been different in any specific way? We believe that it is possible to speak of a new entrepreneurship, which is probably more prevalent in Europe than in the United States, because the crisis of the European welfare systems (in terms of budget, efficiency and legitimacy) has resulted in public authorities increasingly looking to private initiatives to provide solutions that they would have implemented themselves if the economic climate had been as good as in the glorious 1945-1975 period. It is undoubtedly in the United Kingdom that this trend was first seen as the most striking, but it is now apparent, to varying degrees, in most member states of the European Union. The two main fields of activity covered by the works of the EMES European Research Network, namely work integration of low-qualified jobseekers and personal services, have seen multiple innovations in terms of new activities better adapted to needs, whether in regard to vocational training, childcare, services for elderly people, or aid for certain categories of disadvantaged persons (abused children, refugees, immigrants etc.). ${ }^{13}$

This entrepreneurship seems all the more innovative as, even within the third sector, it contrasts sharply with the highly bureaucratic and only slightly innovative behaviour of certain large traditional organisations (for example, the very large welfare organisations - Wohlfahrtsverbände - in Germany).

\section{New methods of organisation and/or production}

It is common to see the third sector organise its activities in ways which differ from the traditional private and public sectors. But what is most striking in the current generations of social enterprises is the involvement of different partners, of several categories of actors: salaried workers, volunteers, users, support organisations and local public authorities are often partners in the same project, whereas traditional social economy organisations have generally been set up by more homogeneous social groups. ${ }^{14}$ If this does not necessarily revolutionise the production process in the strict meaning of the term, it nevertheless often transforms the way in which the activity is organised. In some cases, one could even talk of a joint construction of supply and demand, when providers and users co-operate in the organisation and management of certain proximity services. The setting-up of childcare centres run by parents in France or in Sweden is just one of many examples of such co-operation.

\footnotetext{
11 See also Defourny (2001).

12 That is indeed one of the major themes of the whole literature aiming to identify the main reasons for the existence of the third sector.

13 On the subject of work integration, see Spear et al. (2001) or Davister, Defourny and Grégoire (2004); on personal services, see Laville and Nyssens (2001b).

14 The greater homogeneity of "traditional" social economy organizations is reflected in particular in the names of the different types of co-operatives or mutual societies, e.g. workers' co-operatives, agricultural co-operatives, mutual societies for civil servants, craftsmen, farmers and so on.
} 


\section{New production factors}

One of the major but long-standing specific characteristics of the third sector is its capacity to mobilise volunteer work. In itself, the use of volunteers is thus not innovating; however, it is innovating in numerous recent initiatives insofar as it makes it possible to produce goods or provide services that were not previously available

It is also noteworthy that volunteering has profoundly changed in nature over the last few decades: it seems to be not only much less charitable than forty or fifty years ago, but also less "militant" than in the 1960s or 1970s. Today's voluntary workers are fairly pragmatic and focus more on "productive" objectives and activities that correspond to specific needs. It is not unusual indeed that the entrepreneurial role, in the most commonly used sense of the term (launching an activity), be carried out by voluntary workers.

Paid work has also seen various innovations. On the one hand, many third sector organisations have been at the forefront of experiments regarding atypical forms of employment, such as the hiring of salaried workers in the framework of unemployment reduction programmes, the development of semi-voluntary formulas or of part-time work with very reduced working hours etc. ${ }^{15}$ On the other hand, it can be said that the traditional status of the workers is often "enriched" when the latter are recognised as fully-fledged members of the governing bodies of the social enterprise, with the resultant control and decision-making powers that this implies. ${ }^{16}$

\section{New market relations}

In a growing number of countries there is a trend of public authorities towards "contracting out" practices and towards the development of quasi-markets for certain services which were previously provided by the state or by non-profit private bodies long favoured by the state. Indeed, with a view to reducing costs and ensuring that the services are better adapted to users' needs, public authorities are making an increasing use of calls to tender, which bring different types of providers into competition for public funding linked to the carrying out of previously defined contract specifications. The conservative governments in the UK along the 80's are those that have gone furthest in this direction, but this switch from "tutelary control" to "competitive control" through quasi-markets is becoming more and more commonplace almost everywhere.

Such profound changes in the welfare state inevitably have major consequences at different levels. It is sufficient here to emphasise the factors that tend to accentuate the entrepreneurial character of associations, in the sense that they have an increasing number of characteristics in common with traditional companies and also, in part, in terms of the "new combinations" referred to by Schumpeter: 17

- existing associations find themselves in competitive situations, increasingly with for-profit companies when tendering, and they are consequently obliged to install or reinforce an internal management culture very much modelled on that of the commercial sector;

\footnotetext{
15 These evolutions are noted here obviously without saying that they constitute social advances.

16 Once again, care must be taken when interpreting this evolution: part of this innovative behaviour comes from the organisations themselves, but it is also a question of reactions and adaptations to the impetus or constraints inherent in public policies.

17 On this subject, see Laville and Sainsaulieu (1997).
} 
- the ending of certain public monopolies (for example in Sweden) or of the monopolies enjoyed by large national federations providing social services (for example in Germany) encourage the emergence of new private initiatives (forprofit or non-profit organisations) whose structure, from the outset, is designed taking into account this context;

- last but not least, both for old and for new associations, the economic risk is greater, since their financing henceforward depends on their ability to win these quasi-markets and to satisfy users.

Finally, it goes without saying that market relations are reinforced by the increased demand, among private individuals with adequate financial resources, for certain services that become accessible because of the continued rise in the living standards of an important part of the population. Thus for example, elderly people who receive a decent pension or who have accumulated considerable savings represent new markets, but these are often very competitive. This trend is still reinforced by the fact that money is made available to fund the demand for some proximity services through public policies which cover a significant part of the production costs (for example through a "service voucher" system for house cleaning services, as in Belgium).

\section{New forms of enterprises}

The recent introduction of new legal frameworks in the national legislation of various European states tends to confirm that we are dealing with a somewhat original kind of entrepreneurship (Defourny and Nyssens, 2008a). These legal frameworks are intended to be better suited to these types of initiatives than the traditional non-profit or co-operative legal forms.

We have already mentioned the new status created in 1991 for Italian social cooperatives. Laws were introduced in other EU countries as well, along the same "cooperative" line, to create new legal forms: the "social solidarity co-operative" in Portugal (1997); the "social initiative co-operative" in Spain (1999); the "limited liability social co-operative" in Greece (1999), the "collective interest co-operative society" in France (2001), and the "social co-operative" (2006) in Poland. Other laws have also been introduced which do not refer explicitly to the co-operative model, even though the latter sometimes inspired them. Thus, in 1995, Belgium created the "social purpose company", and a new law creating the "community interest company" legal form was passed in the United Kingdom in 2004. Moreover, Finland (in 2004) and Italy (in 2006) created a "social enterprise" legal framework which goes beyond the social co-operative model.

Generally speaking, these new legal frameworks are designed to encourage entrepreneurial dynamics towards the fulfilment of a social mission, often with a dominant market orientation. They are sometimes linked to specific public programs aiming at work integration of the hard-to-place (for instance in Poland and Finland). In various cases, they also provide a way of formalising the multi-stakeholder nature of numerous initiatives, by involving the various stakeholders (paid workers, voluntary workers, users etc.) in the decision-making process. However, it must be emphasised that in many countries, the great majority of social enterprises are still using traditional third sector legal forms. 


\section{European approaches of social enterprise}

Although current debates on social entrepreneurship in Europe are more influenced by US debates than before 2005, especially through business schools and a few foundations, it may be stated that two definitions of the social enterprise have been emerging consistently in Europe and now constitute conceptual reference points for a set of international works: the definition forged by the EMES European Research Network in the late 1990s, and that put forward by the British government in $2002^{18}$.

\subsection{The British approach.}

In a paper entitled "Social Enterprise: A Strategy for Success", (2002), the Secretary of State for Trade and Industry, P. Hewitt and the Social Enterprise Unit (SEU) within her Department put forward a definition which served as a basis for a whole policy of the Blair government fostering social enterprises. It states that "a social enterprise is a business with primarily social objectives whose surpluses are principally reinvested for that purpose in the business or in the community, rather than being driven by the need to maximise profit for shareholders and owners" (DTI, 2002). Based upon this definition, a series of empirical studies were carried out across the country and the Social Enterprise Unit commissioned a synthesis of these works (Ecotec, 2003). That report underlined a series of difficulties in terms of consistency and compatibility to make the definition operational. With a view to redressing these shortcomings, the report recommended breaking down the definition into a set of characteristics or indicators, which would be more useful than an "overall statement" in creating an inventory of social enterprises in the United Kingdom. In the same perspective, the Social Enterprise Coalition, the main umbrella body which also plays a key role in fostering a national strategy, proposed to use three main criteria: in addition to a market orientation and social aims, it highlighted a third criterion of social ownership defined by governance and ownership structures based on participation and control by stakeholder groups or by trustees or directors.

In spite of such conceptual efforts, various criteria were used in subsequent surveys, notably regarding the proportion of market-based income in social enterprise's resources and the legal framework under which the enterprise is registered. A survey only covering entities registered as Companies Limited by Guarantee or Industrial and Provident Societies concluded there were around 15,000 social enterprises in the UK in 2004, employing 475,000 workers and a further 300,000 people on a volunteer basis. It was estimated that $88 \%$ of those social enterprises had generated at least $50 \%$ of their income from trading (IFF Research Ldt, 2005). An even greater majority described their mission in terms of helping people, especially persons with disabilities, children or young people, the elderly and people with low incomes. The main way in which people were helped was through training/education and various forms of personal support (housing, childcare, etc.), professional support (business advice, help to look for jobs, etc.) and cultural and recreational opportunities (sports clubs, arts groups, etc.).

One year later, the Annual Survey of Small Businesses included four questions to enable the identification of social enterprises. Now covering all types of SMEs, it

\footnotetext{
18 Of course, the Italian law adopted in 1991 also remains a milestone and still inspires various policies in Europe and elsewhere. However, it is dedicated to two specific types of social co-operative: those delivering social, health and educational services, called "A-type social co-operatives", and those providing work integration for disadvantaged people, referred to as "B-type social co-operatives".
} 
came out with a much larger figure: $5 \%$ of all businesses, that is 55,000 enterprises with employees were said to satisfy all the following: think themselves as a social enterprise; never pay more than $50 \%$ of profits to owners/shareholders; generate more than $75 \%$ of income from traded goods/services (or receive less than $20 \%$ of income from grants and donations); and think they are a very good fit with the government definition of a social enterprise (Institute for Employment Studies, 2006). Although that impressive figure is now often quoted, the understanding of the definition may have been somehow influenced by the fact that "social/environmental objectives" are not defined at all and are instead indirectly presented as opposed to "the need to maximize (not just make) profits for shareholders and owners". Another key item of the definition states that surpluses may be simply "reinvested in the business" (or the community), a rather natural strategy for small businesses owned by sole proprietors which represent a significant part of SMEs surveyed.

In addition to operational limits of the government's definition of social enterprise, the concept itself is still heavily debated in the UK, including as to governance issues (Spear, Cornforth and Aiken 2009). Indeed it is sometimes seen as a "re-branding" strategy to foster market orientation and business methods in existing third sector organizations as well as a major risk of weakening other specificities of the latter ${ }^{19}$. This probably explains why the British government appointed a Minister of the (whole) Third Sector within the Cabinet Office in 2006 and decided to locate the Social Enterprise Unit in the Office of the Third Sector (in charge of the entire "world" of voluntary and community organizations, charities, co-operatives, mutuals, social firms, etc.). Such a move has sometimes been interpreted as weakening the very specific attention paid to social enterprises. From an academic point of view however, there is still a growing interest in those organizations, as shown by initiatives such as an annual "Social Enterprise Research Conference" (since 2004), the publication of a Social Enterprise Journal (since 2005) and the setting up of a major Third Sector Research Centre heavily financed by the Economic and Social Research Council, including for various activities related to social enterprise (2008).

Moreover, it should be stressed that some university centres such as the Skoll Centre for Social Entrepreneurship at Oxford University and others have played a major role in building bridges between European and US debates on social enterprise ${ }^{20}$ as well as between the UK and continental Europe. ${ }^{21}$

Finally, the most recent works in the UK are clearly less focussed on the frontiers of a social enterprise sector or its overall economic weight. They rather acknowledge the very wide diversity of forms, contexts and dynamics which may be observed, as shown by Peattie and Morley (2008).

\subsection{The EMES approach}

It is precisely the need to account for such a diversity which was the major concern of the EMES European Research Network built in 1996 by researchers from all fifteen countries which formed the European Union by that time. Through a major research project financed by the European Commission and covering five years, those scholars tried to analyse to what extent social enterprises were emerging

\footnotetext{
${ }^{19}$ In contrast to its three above mentioned criteria, the Social Enterprise Coalition which is "the voice of the sector" often uses an even more simple definition of social enterprise described as "a business that trades for a social purpose".

${ }^{20}$ See especially Nicholls (2006) in the UK.

${ }^{21}$ See for instance Spear et al. (2001) or Spear and Bidet (2003).
} 
throughout the EU, not only in Italy. ${ }^{22}$ Key features of this approach include the fact that it derived from extensive dialogue among several disciplines (economics, sociology, political science and management) as well as among the various national traditions and sensitivities present in the European Union. Moreover, it was guided by a project that was both theoretical and empirical.

From the outset, the EMES approach gave priority to the choice of various indicators which would help identify social enterprises over a concise and elegant definition. It was also clear that those indicators should not be seen as conditions to be fulfilled to deserve the name of social enterprise. In order to make this key point even clearer, it was explained in a second EMES major work, that "rather than constituting prescriptive criteria, these indicators describe an "ideal-type" (i.e. an abstract construction in Weber's terms), which constitutes a tool, somewhat analogous to a compass which can help the researchers locate the position of certain entities relative to one another $(\ldots)$ within the galaxy of social enterprises." 23

The EMES conceptual framework is based on two series of indicators, some being more economic and the others predominantly social. ${ }^{24}$

To reflect the economic and entrepreneurial dimensions of initiatives, four criteria have been put forward:

\section{a) A continuous activity producing goods and/or selling services}

Social enterprises, unlike some traditional non-profit organisations, do not normally have advocacy activities or the redistribution of financial flows (as, for example, many foundations) as their major activity, but they are directly involved in the production of goods or the provision of services to people on a continuous basis. The productive activity thus represents the reason, or one of the main reasons, for the existence of social enterprises.

\section{b) A high degree of autonomy}

Social enterprises are created by a group of people on the basis of an autonomous project and they are governed by these people. They may depend on public subsidies but they are not managed, be it directly or indirectly, by public authorities or other organisations (federations, private firms etc.). They have both the right to take up their own position ("voice") and to terminate their activity ("exit").

\footnotetext{
22 The letters EMES stand for "EMergence des Enterprises Sociales en Europe" - i.e. the title in French of the first research project of this network. The acronym first designated the researchers' network for the DG Research of the European Commission, which funded the project; it was subsequently retained when the network went on to conduct other research projects on social enterprises and the social economy as a whole. Nowadays, the EMES European Research Network brings together ten university research centres specialized in these fields and several individual researchers throughout Europe. See www.emes.net.

23 Defourny and Nyssens (2006: 7). In spite of this, EMES indicators have often been seen as the EMES definition of social enterprise in a rather traditional way. In its first book, EMES had probably contributed to such a misunderstanding as those indicators were presented as a "working definition" which proved to be fairly robust and reliable although it was also stressed that social enterprises were appearing in each country as a wide spectrum of organizations for which the fulfilment of those criteria varied greatly (Defourny, 2001).

24 They are presented here as in the introduction of the first EMES book (Defourny, 2001: 16-18). This set of criteria had already been identified in the interim reports to the European Commission (EMES European Research Network 1997 and 1998) as well as in a short unpublished paper (EMES, 1999). It inspired the OECD as early as 1999.
} 


\section{c) A significant level of economic risk}

Those who establish a social enterprise assume totally or partly the risk inherent in the initiative. Unlike most public institutions, their financial viability depends on the efforts of their members and workers to secure adequate resources.

\section{d) A minimum amount of paid work}

As in the case of most traditional non-profit organisations, social enterprises may also combine monetary and non-monetary resources, voluntary and paid workers. However, the activity carried out in social enterprises requires a minimum level of paid workers.

To encapsulate the social dimensions of the initiative, five criteria have been proposed:

\section{e) An explicit aim to benefit the community}

One of the principal aims of social enterprises is to serve the community or a specific group of people. In the same perspective, a feature of social enterprises is their desire to promote a sense of social responsibility at the local level.

\section{f) An initiative launched by a group of citizens}

Social enterprises are the result of collective dynamics involving people belonging to a community or to a group that shares a well-defined need or aim; this collective dimension must be maintained over time in one way or another, even though the importance of leadership - often embodied by an individual or a small group of leaders - must not be neglected.

\section{g) A decision-making power not based on capital ownership}

This criterion generally refers to the principle of "one member, one vote" or at least to a decision-making process in which voting power is not distributed according to capital shares on the governing body which has the ultimate decision-making rights. Although the owners of capital are important when social enterprises have equity capital, the decision-making rights are generally shared with the other stakeholders.

\section{h) A participatory nature, which involves various parties affected by the activity}

Representation and participation of users or customers, influence of various stakeholders on decision-making and a participative management are often important characteristics of social enterprises. In many cases, one of the aims of social enterprises is to further democracy at the local level through economic activity.

\section{i) A limited profit distribution}

Social enterprises not only include organisations that are characterised by a total nondistribution constraint, but also organisations which - like co-operatives in many countries - may distribute profits, but only to a limited extent, thus allowing to avoid a profit-maximising behaviour.

As already underlined, these economic and social indicators can be used to identify totally new social enterprises, but they can also lead to designate as social enterprises older organisations which have been reshaped by new internal dynamics. In such a perspective combined with its "ideal type" nature, the EMES approach proved to be empirically fertile. For example, when J.-F. Draperi (2003) studied 151 organisations subsidized over a twenty-year period by France's Fondation Crédit Coopératif, he found in varying degrees most of the features outlined above. Although he did not 
intend originally to adopt the "social enterprise" approach, this is what he finally ended up doing; with reference to the EMES approach, he underlined the capacity for social innovation demonstrated by these organisations.

In a similar perspective, EMES researchers made an inventory of the different types of social enterprises working in the field of on-the-job training and occupational integration of low-qualified individuals. This survey, which covered 12 EU countries, combined the indicators to which we have referred above with criteria peculiar to this field and came up with the concept of the "work-integration social enterprise" (WISE). This conceptual framework allowed identifying 39 categories or models of WISEs in the twelve countries surveyed. ${ }^{25}$ On that basis, another major research project funded by the European Commission was also carried out to test empirically various hypotheses which may be seen as the first building blocks of a European theory of social enterprise (Nyssens, 2006). ${ }^{26}$

\section{Some examples from the European Union}

\section{The European Union before its enlargement in 2004 (EU-15)}

In their first study (1996-1999) ${ }^{27}$, which included the 15 countries composing the European Union at the time, the EMES Network's researchers had devoted themselves to describing and analysing social enterprises emerging in one or several of the three following fields: training and reintegration through work, personal services and local development.

Some of the national realities surveyed are listed in Table 1, whose main objective is to provide an illustration of the conceptual developments we have described above.

Table 1 - Examples of social enterprises in EU-15

\begin{tabular}{|c|c|c|}
\hline Sectors & Countries & Examples \\
\hline \multirow{7}{*}{$\begin{array}{l}\text { Personal } \\
\text { services }\end{array}$} & Austria & $\begin{array}{l}\text { Children's Groups: childcare services supported by a high level of parental } \\
\text { involvement. }\end{array}$ \\
\hline & France & $\begin{array}{l}\text { Crèches parentales (parent-led childcare organisations): childcare services partly } \\
\text { led and managed by parents. These organizations have formed a national } \\
\text { network. }\end{array}$ \\
\hline & Denmark & $\begin{array}{l}\text { Opholdssteder (social residences): residential institutions designed as an } \\
\text { alternative to conventional institutions for children and adolescents with } \\
\text { difficulties. They focus on training and care services. }\end{array}$ \\
\hline & United Kingdom & $\begin{array}{l}\text { Home Care Co-ops: co-operatives employing their members, mainly women with } \\
\text { dependents at home, on a part-time basis. }\end{array}$ \\
\hline & Sweden & $\begin{array}{l}\text { LKUs: co-operative local development agencies organised at the national level } \\
\text { (FKU); their objective is to rehabilitate and reintegrate individuals with a mental } \\
\text { handicap. }\end{array}$ \\
\hline & Italy & $\begin{array}{l}\text { Cooperative sociali di tipo A (A-type social co-operatives): co-operatives active } \\
\text { in the fields of health, training or personal services, operating within the legal } \\
\text { framework adopted by Italy's national Parliament in } 1991 \text {. }\end{array}$ \\
\hline & Portugal & $\begin{array}{l}\text { CERCIs: co-operatives for the training and rehabilitation of handicapped } \\
\text { children; they merged into a national federation in } 1985 .\end{array}$ \\
\hline
\end{tabular}

\footnotetext{
25 The country studies were published in the EMES Working Papers Series. For a synthesis, see Spear and Bidet (2003) and Davister, Defourny and Grégoire (2004).

26 See section 5 hereafter.

27 Borzaga and Defourny (2001).
} 


\begin{tabular}{|c|c|c|}
\hline \multirow{5}{*}{$\begin{array}{l}\text { Training- } \\
\text { integration } \\
\text { through work }\end{array}$} & Belgium & $\begin{array}{l}\text { Entreprises de formation par le travail (EFTs, on-the-job-training enterprises) } \\
\text { and enterprises d'insertion (EIs, work-integration enterprises) in the Southern } \\
\text { part of the country; invoegbedrijven (work-integration enterprises) and sociale } \\
\text { werkplaatsen (social workshops) in the Northern part of the country. }\end{array}$ \\
\hline & Italy & $\begin{array}{l}\text { Cooperative sociali di tipo B (B-type social co-operatives): co-operatives active } \\
\text { in the field of work-integration of individuals in precarious situations (1991 legal } \\
\text { framework). }\end{array}$ \\
\hline & Germany & $\begin{array}{l}\text { Soziale Betriebe (social enterprises): these market-oriented social enterprises } \\
\text { receive temporary public assistance. Their goal is to create jobs and promote } \\
\text { economic development while aiming at the social and occupational integration of } \\
\text { the long-term unemployed. The jobs are created either in existing private } \\
\text { enterprises or within the framework of the starting-up of new enterprises. }\end{array}$ \\
\hline & Luxembourg & $\begin{array}{l}\text { Associations (and sometimes co-operatives) providing their members with } \\
\text { integration through work and economic activities in various fields, including } \\
\text { environment, agriculture, construction, recycling of waste etc.; most are pilot } \\
\text { projects subsidised by the state. }\end{array}$ \\
\hline & Spain & $\begin{array}{l}\text { Work-integration enterprises for the handicapped or individuals excluded from } \\
\text { the conventional labour market. In both cases, the current trend is to provide } \\
\text { access to transitional employment designed to ultimately integrate the target } \\
\text { groups into the conventional labour market, rather than providing them with } \\
\text { long-term "sheltered" jobs. }\end{array}$ \\
\hline \multirow{4}{*}{$\begin{array}{l}\text { Local } \\
\text { development }\end{array}$} & Finland & $\begin{array}{l}\text { Labour co-ops, organised by region into nine Cooperative Development Agencies } \\
\text { (CDAs); they constitute an important lever for economic development at the local } \\
\text { and regional levels. These cooperatives differ from traditional workers' } \\
\text { cooperatives in that they subcontract their members' services to other enterprises. }\end{array}$ \\
\hline & The Netherlands & $\begin{array}{l}\text { BuurtBeheer Bedrijven (BBB, neighbourhood management enterprises): } \\
\text { independent enterprises developing proximity services; they provide the } \\
\text { inhabitants of disadvantaged neighbourhoods with the opportunity to perform } \\
\text { paid work either in the maintenance/improvement of private residences and } \\
\text { shared infrastructure or by providing social services in their neighbourhood. }\end{array}$ \\
\hline & Greece & $\begin{array}{l}\text { Agri-tourism cooperatives: cooperatives set up by women living in rural areas } \\
\text { with tourism potential; they provide services in the areas of accommodation, } \\
\text { catering and small crafts. }\end{array}$ \\
\hline & Ireland & $\begin{array}{l}\text { Local community development enterprises with various legal forms; they provide } \\
\text { a variety of services, including social housing, work-integration, credit (credit } \\
\text { unions), proximity services etc. }\end{array}$ \\
\hline
\end{tabular}

More generally, social enterprises in France (as in Belgium) seem to be particularly innovating in the area of "proximity services". These social enterprises often mobilise additional resources beside resources from the market and the state, and they go beyond the functional logic of the latter. This also clearly shows in the thousands of Italian co-operatives providing social services (residential or not), in particular services intended for the handicapped, elderly people, drug-users and young people with family problems. In the United Kingdom as well, home-care co-operatives emerged in answer to state or market failures, in a specific context characterised by the rapid development of quasi-markets.

The border between the provision of social services and activities aiming to reintegrate persons excluded from the labour market is relatively blurred. Indeed, in several countries, social work or services for handicapped persons or persons with other difficulties evolved towards more productive activities. The latter then served as the basis for the creation of social enterprises offering temporary (or even stable) jobs. The case of Denmark provides a good illustration of this hybrid nature; in this country, social work, community development and productive activities are intertwined in various types of initiative such as "production communities", "social residences" (opholdssteder) or "people's high schools" (folkehøjskoler) - the two latter 
types being known for their capacity to deal with young people with social problems. In Sweden, since the state initiated a reform including the phasing out, during the 1980s, of the large mental heath institutions, social work co-operatives have developed for the former patients of these institutions, as well as for handicapped persons. Although these co-operatives do not provide "traditional" jobs, they demonstrate an entrepreneurial spirit which is encouraged by co-operative local development agencies. In a very different context, Portuguese CERCIs (co-operatives for the training and rehabilitation of mentally handicapped children) were originally special schools; they gradually evolved as their users grew up, acquiring an increasingly marked orientation towards production and job-creation.

In many cases, the border is not clear-cut either between social enterprises aiming at the occupational integration of handicapped persons and those targeting socially excluded persons (drug-users, prisoners, young drop-outs...). Social enterprises of the two types (and sometimes even mixing the two target groups) can be identified in Italy, Luxembourg, Greece and Spain, in various fields of activity. In the latter country, collection of waste and recycling activities are particularly important.

Many social enterprises offer stable jobs, but many others must be considered as linked to "transitional labour markets"; in other terms, these enterprises constitute a stage on the reintegration path towards the traditional labour market. For example, various initiatives in Germany (in particular those specifically termed "social enterprises" in three Länder) and Finnish labour co-operatives (which provide jobs to their members by "subcontracting" their work to other employers) can be considered as transitional institutions receiving temporary support from public authorities.

Finally, we should also underline the participation of social enterprises to local development dynamics in disadvantaged areas. This is particularly true of organisations of the "ABS" type in the new Länder of the former East Germany, of agri-tourism co-operatives (managed by women in isolated rural regions) in Greece as well as of neighbourhood development/rehabilitation programmes in rural zones in the Netherlands. Sometimes, concerns for local development are predominant, as in Ireland, where a large array of initiatives in the area of proximity services as well as community enterprises would not have emerged without the mobilisation of local populations and the setting up of local partnerships.

\section{The Central and Eastern European Countries}

There has not been yet an in-depth study of the realities of social enterprises in most Central and Eastern European Countries (CEEC), comparable to the one conducted by EMES in the 15 countries which constituted the European Union prior to its enlargement in 2004. Nevertheless, with support of the UNDP, EMES recently carried out an overview study on the potential of social enterprises in CEE and several countries of the $\mathrm{CIS}^{28}$. Combined with some earlier works ${ }^{29}$, that study allowed to highlighting some general trends.

\footnotetext{
28 Borzaga, Galera and Nogales (2008). That study was carried out in collaboration with local researchers and it covered six new EU member countries (Bulgaria, Czech Republic, Estonia, Lithuania, Poland and Slovenia), two Balkan countries ( Macedonia and Serbia) and four countries of the Community of Independent States (Belarus, Kazakhstan, Russia and Ukraine). It also included a more detailed analysis for three countries selected from those subgroups (Poland, Serbia and Ukraine). ${ }^{29}$ In particular Borzaga and Spear (2004) and Borzaga and Galera (2004).
} 
In contrast to the situation in Western Europe, several obstacles are hampering recognition of the real potential of social enterprises:

- the dominance of the "transition myth" which, until now, induced policies highly reliant on the creation of a free market and failing to appreciate the value of "alternative" organisations and enterprises as bona fide forces for local and national development;

- the neo-liberal paradigm (espoused by the media, the elites and the politicians), dismissive of collective and solidarity values;

- a cultural opposition to co-operatives and a belief that they are somehow politically suspect. In many countries, there is a negative perception of old co-operatives as organisations with ties to former Communist regimes - even though many of these organisations were actually created before the Communist era;

- an excessive dependence of social enterprises on donors, combined with a limited view of the role that alternative organisations can play. As regards associations, it appears that many NGOs are created, but they often suffer from two weaknesses. First, they are highly dependent on external donor agencies - especially American foundations - that tend to use them for their own purposes and significantly limit their autonomy. Second, while NGOs sometimes emerge as forces that are certainly associative, they are often less an authentic expression of civil society than the upshot of strategies linked to funding opportunities;

- a general lack of confidence in solidarity movements - the concept of solidarity being used primarily to describe an individual's relationship with friends and family - and a view of economic activity as oriented towards the pursuit of personal gain, rather than as an activity with positive benefits for the community as a whole;

- the predominance of a "parochial" political culture inducing, among social economy actors, a tendency to limit their horizons to the pursuit of their immediate interests; the networking capacity of third sector organisations (be it among the various "families" of the third sector associations, co-operatives, foundations - or within families) is low;

- the difficulty in mobilising the necessary resources.

However, despite the cultural, political and legal difficulties they face, both traditional co-operatives and the new generations of non-profit organisations display a real potential for growth. Indeed, several factors affect the third sector in a positive way: the legacy of the strong pre-soviet tradition of charitable organisations and cooperatives constitutes an asset for the third sector; the level of education of third sector leaders is high; all countries covered by the EMES study display a capacity of creation of grassroots initiatives; and rural areas are characterised by strong social capital and local links.

It has also been noted that when co-operatives return to their roots, they can play an important role in regions with underdeveloped markets. The re-emergence of credit co-operatives in Lithuania bears testimony hereto. So does the example of Poland, where interesting co-operative initiatives have arisen in different areas, including credit, housing and agriculture. In Estonia, the co-operative sector, which took off in 
the 1990s, has now become a cornerstone of Estonia's social economy, among others through the creation of the Estonian Union of Co-operative Housing Association, which gathers more than 7000 organizations ${ }^{30}$.

New types of third sector organisations are also emerging in Central and Eastern Europe. Some of these can be seen as forms of social entrepreneurship, provided the latter is understood in a reasonably "flexible" way ${ }^{31}$. These organisations are starting to provide services of general interest, redressing the failures of the social system. There are now associations in all CEEC, and foundations in all except Latvia and Lithuania. A few countries have also created "open foundations", which result from the convergence of some associations and foundations.

The legal environment in CEEC indeed appears as rather favourable; some countries have even gone so far on the way to the legal recognition of social entrepreneurship as to create specific legal frameworks for social enterprises. In Hungary, for example, public interest companies (closely related in form to UK's Community Interest Company) provide public services, while pursuing economic activities to raise funds for these services. Poland, Slovenia, the Czech Republic and Lithuania all provide examples of recently adopted specific legal frameworks for social enterprises ${ }^{32}$. In Poland, the Act on Social Employment (2003) and the Act on Employment Promotion and Institutions of the Labour Market (2004) already constituted a legal recognition of social entrepreneurship of low-income groups; further recognition was attained in June 2006 with the creation of a separate legal form for social co-operatives, whose aim is the social and occupational integration of jobless or handicapped people ${ }^{33}$. In Slovenia, a specific form of income-generating non-profit organization has been introduced: the private not-for-profit institute. The latter is a legal entity performing activities in the field of education, science, culture, sports, health or social affairs; private not-for-profit institutes' most important source of income is constituted by commercial activity on the market. The Czech law instituting the Public Benefit Company (which, as its name indicates, is committed to supply services of public benefit) and the Lithuanian law on social enterprises are not flawless, but they nonetheless both constitutes significant steps towards the legal and institutional recognition of social entrepreneurship in the CEEC.

In sum, despite the problems associated, inter alia, to the process of economic transition in which CEEC are engaged, social enterprises in these countries are showing significant growth potential. Co-operatives are regaining ground in some of their traditional roles, and the new associative models that have emerged in Eastern Europe confirm the relevance of the social enterprise model.

\section{Paving the way to a theory of social enterprise}

In the last phase of its first major research, the EMES Network took the initial steps towards the progressive development of a specific theory of social enterprise. In such a perspective, Bacchiega and Borzaga (2001) used tools from the new institutional economic theory to highlight the innovative character of social enterprises; the

\footnotetext{
30 Otsing (2004).

31 The EMES approach of social enterprise has been adapted for the purpose of the study conducted in CEE and the CIS, in order to take into account the local contexts and specificities. This "adapted" working definition only includes three economic and three social criteria (EMES, 2006:.61 and Borzaga, Galera, Nogales, 2008: 75-76).

32 However, not all these laws explicitly use the term "social enterprise".

33 CECOP (2006).
} 
characteristics defining the social enterprise were interpreted as forming an original system of incentives that takes into account the potentially conflicting objectives pursued by the various categories of stakeholders. Evers (2001) developed a more socio-political analysis to demonstrate that such a "multi-stakeholder, multiple-goal" structure was more easily understood if making use of the concept of "social capital". For Evers, creating social capital can also constitute an explicit objective of organisations such as social enterprises. Laville and Nyssens (2001a) came up with elements for an integrated theory of an "ideal type" combining the economic, social and political dimensions of social enterprise. Like Evers, they emphasised the role of social capital, which is mobilised and reproduced in specific forms by social enterprises. In addition, they stressed the particularly hybrid and composite nature of social enterprises' resources (made of market, non-market and non-monetary resources such as volunteering), viewing this as a major asset of these organisations to resist the trend toward "institutional isomorphism" that threatens all social economy organisations.

Within a second major research project, those theoretical lines were transformed into hypotheses to be tested for work integration social enterprises through a large survey conducted in twelve EU countries (Nyssens, 2006). Carried out over ten years, those two EMES projects and books may be regarded so far as the most comprehensive integrated work combining an original theoretical perspective with a large comparative empirical research across Europe.

Theoretically, the social enterprise concept could also point the way toward a more integrated approach to the entire social economy. As a matter of fact, when apprehending the social economy, two sources of tension appear as recurrent and difficult to overcome. One source of tension originates in the gap between enterprises offering their entire output for sale on the market (as do most co-operatives) and associations whose activities do not have a strong economic character (such as youth movement activities) and whose resources are totally non-market (grants, subsidies, etc.), or even non-monetary (volunteering). A second tension exists between socalled mutual interest organisations (co-operatives, mutual societies and a large part of associations) which, at least in principle, aim to serve their members, and general interest organisations, serving the broader community or specific target groups outside their membership (such as organisations fighting poverty and exclusion, or those involved in development co-operation, environmental protection and so on) ${ }^{34}$.

These two sources of tension are partly illustrated in figure 1 hereafter. The first source of tension is represented by the coexistence of two distinct spheres: one sphere represents the co-operative tradition (which generated specific literature and schools of thought), while the other sphere represents the tradition of associative initiatives and movements (which has also inspired numerous sociologists and political scientists, especially in the North-American literature on non-profit organisations). The second source of tension is more difficult to depict: it may be seen, although partly, within each of the two spheres, where general interest organisations are rather located in the area towards the centre, whereas the mutual

\footnotetext{
34 This second tension should not be exaggerated, though; it translates a "historical" difference between two models of actions rather than a clear-cut difference between the contemporary practices. For example, gradually, along their development path, many mutual societies and user co-operatives have started to offer their goods and services to non-member customers, with advantages very similar to those offered to members.
} 
interest organisations tend to be located either on the left or on the right of the diagram (although some advocacy NPOs may of course be of general interest).

The unifying role of the social enterprise concept resides primarily in the fact that it generates mutual attraction between the two spheres. It accomplishes this by drawing certain organisations within each sphere towards the central zone and by including them into a single group of organisations because they actually are very close to each other. Whether they choose a co-operative legal form or an associative legal form depends primarily on the legal mechanisms provided by national legislations.

On the left hand (co-operative) side, social enterprises may be seen as more oriented to the whole community and putting more emphasis on the dimension of general interest than many traditional co-operatives. This is of course the case for enterprises registered as social co-operatives as well as, among others, for co-operatives for the handicapped in most CEE countries. On the right hand (non-profit) side, social enterprises place a higher value on economic risk-taking related to an ongoing productive activity than many traditional associations, including advocacy or grantmaking organizations.

Lastly, by going beyond the two spheres, the dotted lines suggest yet another point to be considered: although most social enterprises take the form of co-operatives or associations across Europe, they can also develop, as already mentioned, within the framework of other legal forms.

\section{Figure 1}

Social enterprise at the crossroads of the co-operative and non-profit sectors

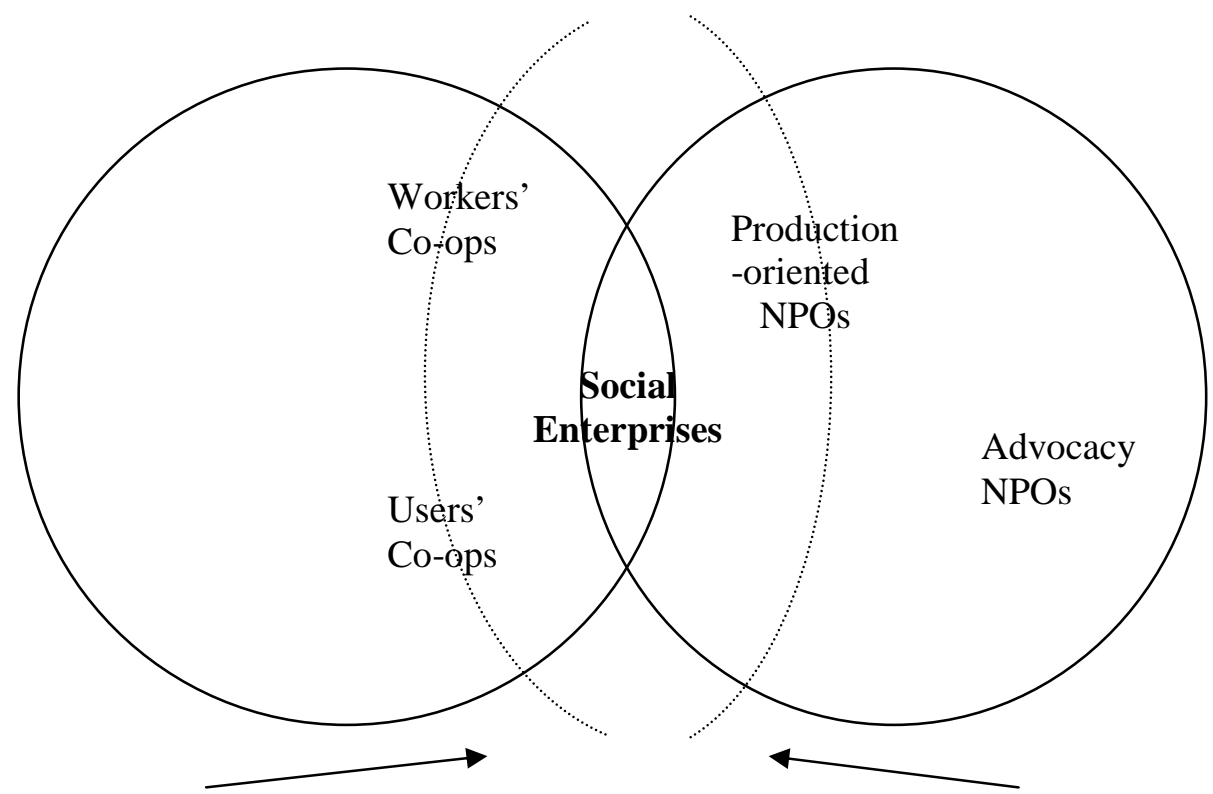

Source: Adapted from Defourny (2001:22) 


\section{Toward a dialogue with Anglo-Saxon approaches}

Figure 1 could also be used to illustrate, although imperfectly, the two initial movements which, in Italy and the US, led to the emergence of the notion of social enterprise. Italian social co-operatives have embodied, from the early 1990s, a desire to use the co-operative model to develop the provision of social services to disadvantaged groups, often in the framework of contracts with local public authorities. By doing so, they broadened the traditional co-operative model and got closer to areas traditionally occupied by non-profit organizations in many European countries. Conversely, the quest for market resources by US non-profit organizations led the latter to adopt commercial practices inspired by the business world. As commercial enterprises, co-operatives do belong to this business world although the proximity of social enterprises and co-operatives appears more clearly in the British context as described earlier.

In order to adequately depict the US scene, which does not seem to give an explicit place to co-operatives, one should emphasize the whole business community and its various interactions with social entrepreneurship. One should first recall the major role played by a growing number of private foundations. Most of these are endowed by large family fortunes, often originated in business activities. They encourage initiatives with a social purpose, generally of the non-profit type, to adopt incomegenerating strategies inspired by the business world ${ }^{35}$. Another aspect of social enterprises' interactions with the business world is constituted by the partnerships which are established, with increasing frequency, between large private groups and non-profit organisations, be it for the commercialization of products linked to societal issues (for example in the field of fair trade or ethical finance), for the joint creation of societies in new industries (for example linked to sustainable development) or for any other form of collaboration. Finally, a great variety of initiatives - from sponsoring and patronage to other, more innovative forms such as social venture capital - can occur in the framework of "corporate social responsibility" (CSR) strategies, and many business schools will be prompt to consider these as "social entrepreneurship".

In other terms, one of the most prominent/outstanding characteristics of US social entrepreneurship is certainly its quest for commercial resources and, more generally, a kind of "tropism" towards the market and the business world (Kerlin, 2006). Although such dynamics do also exist in Europe, social enterprises there are influenced, to a much more significant extent, by the evolution of public policies, be it in the fight against unemployment, the development of personal services or other fields deemed important by governments. This major difference is clearly reflected in scientific works. Scholars and consultants from the Anglo-sphere, for example, often consider the degree of self-funding (through sales) as a the key criterion or, still better, as the main axis along which initiatives that can be considered as forms of social entrepreneurship can be classified (always keeping in mind, though, that social entrepreneurship's main goal is to serve a more or less innovating "social mission").

\footnotetext{
35 According to the "Social Enterprise Alliance", created in 2002 by various foundations and support organizations, a social enterprise is "any earned-income business or strategy undertaken by a nonprofit to generate revenue in support of its charitable mission". This vision is also found for example in the various programmes of the NESsT (Nonprofit Enterprise and Self-sustainability Team). In reality, as soon as the 1980s, many works analyzed the question of the funding of nonprofit organizations, although these works did not use the term "social enterprise" (see for example Skloot 1983 or Young 1983).
} 
Nicholls (2006), for example, puts forward a classification of social entrepreneurship along a continuum ranging from "voluntary activism", based only on gifts and volunteering, to "corporate social innovation", which consists in risky investment for a social purpose within the framework of a for-profit private company. Between these two extremes, he describes various types of non-profit organisations, ranging from those which are totally funded by subsidies to those which are totally self-funded. In his analysis, only the latter deserve the "social enterprise" label; this indeed corresponds to a dominant trend in the US context as well as to the vision of the Social Enterprise Coalition in the U.K. when stating that a social enterprise is a business that trades for a social purpose.

In Continental Europe, the notion of social entrepreneurship is becoming more popular although still less widespread than in the US. As in the latter, it seems increasingly easy to speak of social entrepreneurship as a very broad array of initiatives, well beyond the third sector: the notion of entrepreneurship itself can be understood in many different ways and its combination to a social orientation may refer to practices including various forms of corporate social responsibility, publicprivate partnerships with a social aim, or even public sector adoption of business skills ${ }^{36}$. The EMES Network itself has never claimed to circumscribe, in its works, all the forms of social entrepreneurship; these works have mainly focused on social entrepreneurship dynamics within the third sector. But a radical divergence between the dominant US approach and this European one appears as regards the more narrow notion of social enterprise: in the European context, it is impossible to ignore the embedding of very numerous social enterprises in public policies and the existence of social enterprises that derive a great deal of their income from non-market sources (Defourny and Nyssens, 2008b). For instance, the EMES study of work integration social enterprises (WISEs) throughout the EU abundantly documented the threefold orientation of these enterprises, which are situated at the crossroads of civil society, public policies and market dynamics (Nyssens, 2006).

If European and North-American approaches were to be shown graphically, a possible way to do so might be the one suggested by Hulgård (2007): two spheres should be added to figure 1, representing respectively the role of public authorities and the influence of the business world. Indeed, considering social enterprises as located in a central zone, more or less extended as suggested by the dotted lines, it is possible to see them as possibly resulting from a great variety of interactions. Going downwards, public policies tend to get closer to business methods and market dynamics. This can mean various public authorities' supports to social enterprises or the latter may be considered as having potentially important roles in the restructuring of public services (Spear et al., 2009). When moving upwards, the business world tends to be increasingly concerned with the public good and to get more deeply involved in the setting up of social enterprises.

Beyond comparisons between Europe and the US, such a representation even makes it possible to integrate development paths of the social enterprise landscape such as those emerging in South-Eastern Asia. In South Korea for instance, part of the associative movement which was at the forefront of the struggle for democracy in the

\footnotetext{
36 Leadbeater (1997) already acknowledged the presence of social entrepreneurship across all three sectors of society.
} 
1990s is now advocating and setting up service-providing third sector organizations, especially for the most in need. On its side, the Korean parliament passed a law in 2006 for the promotion of social enterprises devoted to social service delivery or work integration of the hard-to-place while keeping a strong control over those initiatives (Bidet, 2008). Moreover, it is interesting to note that the official website of South Korean social enterprise ${ }^{37}$ claims a dual influence from Europe (mentioning France, Italy and the U.K.) and from the United States (stressing the need to raise more funds from domestic leader companies). As to Japanese social enterprises, they seem to be heavily influenced by US models but a good deal of them are quite close to the cooperative sector, especially some work integration social enterprises looking like workers' cooperatives and consumer co-operatives which have developed social services for the benefit of the community at large.

Figure 2

Social enterprise at the crossroads of public policies, for-profit companies and the third sector

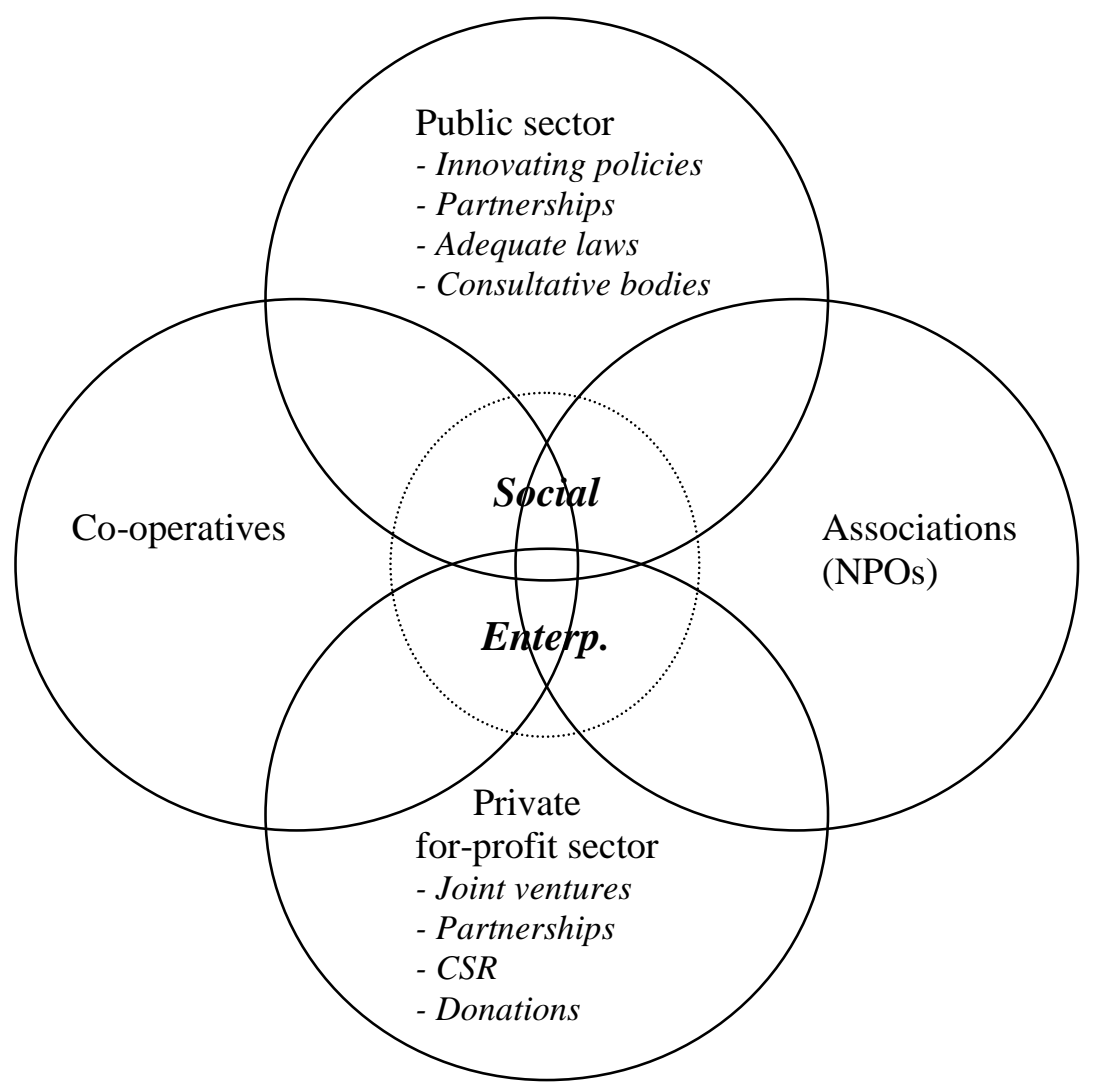

\section{Conclusions}

\footnotetext{
${ }^{37}$ http://www.socialenterprise.go.kr/
} 
Even though not all the practices that it encompasses are new, social entrepreneurship is obviously "trendy", and it keeps diversifying, be it along organisational, industrial, geographical or other dimensions.

Since it is a very recent notion, this growing diversity and the very openness of the concept probably constitute strengths of the latter, and reasons to take it seriously. These are also the reasons for its rapid success, both among public authorities and private sector actors who, both in their own way, are discovering (or rediscovering) new possibilities to promote simultaneously entrepreneurial dynamics and social purposes.

However, beyond this "fashionable" aspect, unstable by nature, which is supported and nourished by enthusiastic and committed promoters, it is important that rigorous analyses be developed - analyses going beyond the success stories and the "heroes" repeatedly set under the limelight. In order to do so, thorough surveys - providing data about actual practices and about failures as well as successes - are absolutely necessary. Moreover, interdisciplinary dialogues constitute are needed to avoid interpretations neglecting fundamental dimensions of the phenomenon. Until now, the entrepreneurial aspect and all issues related to the management of such organisations have been highlighted mostly by management sciences. This is all the more interesting that such approaches contribute to introduce into business schools forms of entrepreneurship hitherto rather little taken into consideration. But as far as the social aspect is concerned, management sciences have probably much to learn from other disciplines which have been exploring the third sector for several decades, even though some trends hereof can sometimes seem to convey an "anti-business" discourse (Dees and Anderson, 2006).

Several works carried out in the US underline the fact that social entrepreneurship tends to blur the borders between the non-profit and the for-profit sectors; these borders are then being replaced by a continuum of forms whose market orientation and for-profit character vary. However, this trend towards "blurring boundaries", which has already been highlighted by several European specialists of the third sector $^{38}$ (also stressing interactions with the public sector), by no way reduces the increasingly recognized importance of the "social economy" or the "non-profit sector" in contemporary economies. Moreover, because the bulk of the third sector remains quite distinct, the fact that many or a majority of social enterprises are rooted in this specific field may well constitute the most reliable guarantee to avoid social entrepreneurship being progressively diluted and loosing most of its strength after a first decade or two of interest for its novelty.

38 For example, among many others, Evers (1995) and Dekker (2004). 


\section{Bibliography}

Bacchiega, A. and Borzaga, C. (2001) "Social Enterprises as Incentive Structures: an Economic Analysis", in Borzaga, C. and Defourny, J. (eds) The Emergence of Social Enterprise, London and New York: Routledge, 273-94.

Badelt, Ch. (1997) "Entrepreneurship Theories of the Non-Profit Sector", Voluntas, vol. 8 , no $2,162-78$.

Bidet, E. (2008) "The Rise of Work Integration and Social Enterprise in South Korea", paper presented at the second EMES-ISTR International Conference, Barcelona, 9-12 July 2008.

Bornstein D. (2004), How to Change the World: Social Entrepreneurs and the Power of NewIdeas, New York: Oxford University Press.

Borzaga, C. and Defourny, J. (eds) (2001) The Emergence of Social Enterprise, London and New York: Routledge (paperback edition: 2004).

Borzaga, C. and Galera, G. (2004) "Social Economy in Transition Economies: Realities and Perspectives", Discussion Paper presented at the First Meeting of the Scientific Group on Social Economy and Social Innovation of the OECD Centre for Local Development, Trento, Italy.

Borzaga, C., Galera, G. and Nogales, R., eds (2008), Social Enterprise: A New Model for Poverty Reduction and Employment Generation, EMES and UNDP Bratislava Regional Bureau.

Borzaga, C. and Santuari, A. (2001) "Italy: from Traditional Co-operatives to Innovative Social Enterprises", in Borzaga, C. and Defourny, J. (eds) The Emergence of Social Enterprise, London and New York: Routledge, 166-81.

Borzaga, C. and Spear, R. (2004) Trends and Challenges for Co-operatives and Social Enterprises in Developed and Transition Countries, Trento: Edizioni31.

CECOP (2006) Social enterprises and worker cooperatives: Comparing models of corporate governance and social inclusion, CECOP European Seminar, Manchester, November 9, 2006.

Davister, C., Defourny, J. and Grégoire, O. (2004) "Work Integration Social Enterprises in the European Union: an Overview of Existing Models", EMES Working Papers Series, no. 04/04. (ww.emes.net)

Dees, J. G. (1998) "The Meaning of Social Entrepreneurship", Stanford University, miméo.

Dees, J. G. \& Anderson B.B. (2006), "Framing a Theory of Social Entrepreneurship: Building on Two Schools of Practice and Thought" in Research on Social Enterpreneurship ARNOVA Occasional Paper Series, vol.1, no 3, pp. 39-66.

Defourny, J. (ed.) (1994) Développer l'entreprise sociale, Bruxelles: Fondation Roi Baudouin.

Defourny, J. (2001) "From Third Sector to Social Enterprise", in Borzaga, C. and Defourny, J. (eds) The Emergence of Social Enterprise, London and New York: Routledge, 1-28.

Defourny, J., Favreau, L. and Laville, J.-L. (eds) (1998) Insertion et nouvelle économie sociale. Un bilan international, Paris: Desclée de Brouwer. 
Defourny, J. and Nyssens, M. (2006) "Defining Social Enterprise" in Nyssens, M. (ed.) Social Enterprise - At the crossroads of market, public policies and civil society, London and New York: Routledge, 3-26.

Defourny, J. and Nyssens, M. (2008a) "Social Enterprise in Europe: Recent Trends and Developments", Social Enterprise Journal, vol.4:3, 202-228.

Defourny, J. and Nyssens, M. (2008b) "Conceptions of Social Enterprise in Europe and the United States: Convergences and Divergences", EMES Working Papers Series, no. 09/02.

Dekker, P. (2004) "The Netherlands: from Private Initiatives to Non-profit Hybrids and Back?", in Evers, A. and Laville, J.-L. (eds), The Third Sector in Europe, Cheltenham: Edward Elgar, 144-165.

Draperi, J.-F. (2003) "L'entreprise sociale en France, entre économie sociale et action sociale" in Revue des Etudes Coopératives, Mutualistes et Associatives (RECMA), ${ }^{\circ}$ 288, 48-66.

DTI (2002) "Social Enterprise. A Strategy for Success", Department of Trade and Industry, London. (www.dti.gov.uk/socialenterprise/strategy.htm)

Ecotec (2003) "Guidance on Mapping Social Enterprise", Final Report to the DTI Social Enterprise Unit, London.

EMES European Network (1997, 1998) "The Emergence of Social Enterprises. A New Answer to Social Exclusion in Europe", Semestrial Progress Reports to the European Commission.

EMES European Network (1999), The Emergence of Social Enterprises in Europe. A Short Overview, Brussels: EMES.

EMES European Research Network (2006) Study on Promoting the Role of Social Enterprises in CEE and the CIS, Initial Overview Study for the UNDP-BRC (Bratislava Regional Centre).

Evers, A. (1995) "Part of the Welfare Mix: The Third Sector as an Intermediate Area" Voluntas, vol. 6:2, 159-182.

Evers, A. (2001) "The Significance of Social Capital in the Multiple Goal and Resource Structure of Social Enterprise", in Borzaga, C. and Defourny, J. (eds) The Emergence of Social Enterprise, London and New York: Routledge, pp. 296-311.

Evers, A. and Laville, J.-L. (eds) (2004) The Third Sector in Europe, Cheltenham: Edward Elgar.

IFF Research Ldt (2005) A Survey of Social Enterprises across the UK, Report prepared for the Small Business Service, London: IFF Research Ltd.

Gueslin, A. (1987) L'invention de l'économie sociale, Paris: Economica.

Hulgård, L. (2007) "Differences between American and European Conceptions of Social Entrepreneurship", paper presented at an international EMES Seminar, Roskilde University.

Institute for Employment Studies (2006), Annual Survey of Small Businesses: UK 2005, London: Small Business Service, DTI.

Kerlin, J. (2006), Social Enterprise in the United States and Europe: Understanding and Learning from the Differences," Voluntas, 17(3), 247-263. 
Laville, J.-L. and Nyssens, M. (2001) "The Social Enterprise: Towards a Theoretical Socio-Economic Approach" in Borzaga, C. and Defourny, J. (eds) The Emergence of Social Enterprise, London and New York: Routledge, 312-32.

Laville, J.-L. and Nyssens, M. (eds) (2001) Les services sociaux entre associations, Etat et marché, Paris: La Découverte et Syros.

Laville, J.-L. and Sainsaulieu, R. (eds) (1997) Sociologie de l'association, Paris: Desclée de Brouwer.

Leadbeather, C. (1997), The Rise of the Social Entrepreneur, London: Demos

Mair, J., Robinson, J., \& Hockerts, K. (eds) (2006), Social Entrepreneurship, New York: Palgrave Macmillan

Nicholls, A. (ed.) (2006) Social Enterpreneurship, New Models of Sustainable Social Change, Oxford University Press.

Nyssens, M. (ed.), (2006) Social Enterprise - At the crossroads of market, public policies and civil society, London and New York: Routledge.

OCDE (1999) Les entreprises sociales, Programme LEED, Paris: OCDE.

Peattie, K. and Morley, A. (2008) "Social Enterprises: Diversity and Dynamics, Contents and Contributions", London: Social Enterprise Coalition and ESRC.

Otsing, M. (2004) "How to Develop a Co-operative Movement. The case of cooperative housing in Estonia", in Borzaga, C. and Spear, R. (eds) Trends and Challenges for Co-operatives and Social Enterprises in Developed and Transition Countries, Trento: Edizioni31.

Schumpeter, J. A. (1934) The Theory of Economic Development, 3d printing, 1963, New York: Oxford University Press.

Skloot E. (1983), "Should Not-for-profits Go into Business?", Harvard Business Review, 61 (1), pp. 20-27.

Spear, R. and Bidet, E. (2003) "The Role of Social Enterprise in European Labour Markets", Working Papers Series, Liège: EMES European Research Network, no 03/10.

Spear, R., Defourny, J., Favreau, L. \& Laville, J.-L., eds. (2001), Tackling Social Exclusion in Europe. The Contribution of the Social Economy, Aldershot: Ashgate.

Spear, R., Cornforth, C. and Aiken, M. (2009), "The Governance Challenges of Social Enterprises: Evidence from a UK Empirical Study", to appear in the Annals of Public and Co-operative Economics.

Steyaert, C. \& Hjorth, D. (eds.) (2006), Entrepreneurship as Social Change, Cheltenham: Edward Elgar.

Young, D. (1983) If Not for Profit, for What?, Lexington, Mass.: Lexington Books. 